\title{
DEVELOPMENT OF A HAND-HELD DISK MOWER POWERED BY SOLAR ENERGY
}

\author{
Arafat $^{1^{*}}$ M.W.M., Mostafa ${ }^{2}$ M.M., Hassan ${ }^{3}$ F.A.A. and ElHelew ${ }^{2}$ W.M.K.
}

1- El-Dakhla Agric. Directorate, New Valley Gov., Egypt

2- Agric. Engineering Dept., Fac. of Agric., Ain Shams Univ., P.O. Box 68, Hadayek Shubra 11241, Cairo, Egypt

3- Agric. Engineering Res. Inst., Ag. Res. Center, Dokki, Giza, Egypt.

*Corresponding author: smart-eng.202014@agr.asu.edu.eg

Received 16 July, 2019

Accepted 24 September, 2019

\section{ABSTRACT}

The current study was conducted to develop a hand held solar powered disk mower by DC motor through a dry battery charged from a solar power plant established on a private farm in El-DakhlaNew Valley by modifying a gasoline-powered machine in an attempt to study the possibility of using solar energy instead of fossil fuel for operating agricultural machinery to overcome the deficit of traditional energy resources and reduce the greenhouse gases and its negative environmental impact. The experimental tests carried out for mowing alfalfa during seasons of 2017/2018; included two tests, firstly preliminary test which performed to identify the morphological and mechanical properties of alfalfa, to obtain the required data for developing a hand held mower and selecting its main components that include "DC motor; battery and solar charger controller. As well as, determine the torque requirement for the cutter disk rotating main shaft. Also; study the state of battery charge to the selected suitable battery. Secondly field tests to evaluate the performance rate; efficiency; energy consumption and operating costs of the developed solar powered machine compared with the gasoline powered machine under field conditions. Two main parameters were studied during the field test; cutter disk rotational speed (3600, 6000,9000 rpm) and Plant density (<6000, 6000$9000, \geq 12000$ plant $/ \mathrm{m}^{2}$ ). The results of the preliminary test indicated that, the alfalfa average stalk height; stalk diameter were $75 \mathrm{~cm} ; 4 \mathrm{~mm}$ and the plant density was ranged between 6000 to 12000 plant $/ \mathrm{m}^{2}$; while its moisture contents during mowing was ranged between 79 to $89 \%$. The maximum cutting force was $130 \mathrm{~N}$ recorded with stalk
\end{abstract}

diameter $4 \mathrm{~mm}$. As well as; the applied torque on the cutter disk shaft recorded when the DC motor fixed directly with the cutter disk ranged between 0.6366 and $0.2546 \mathrm{~N} . \mathrm{m}$. The state of charge (S.O.C) of the selected dry battery "12 voltage", it continues to operate efficiently for about one hour, at charge level $100 \%$ "full charge", in which the voltage was $14 \mathrm{~V}$ then gradually decreases to the level of $20 \%$ "full discharge" then the voltage was 8 volts. The current from the dry battery fluctuated between the maximum of 12 amperes during the cut-off phase to a minimum of 4 amperes during return back (without cutting). The result of field tests indicated that; the actual performance rate with the gasoline powered machine (before modified) was $0.209 \mathrm{fed} / \mathrm{h}$ recorded with plant density 6000 plant $/ \mathrm{m}^{2}$ and cutter disk rotational speed 3600 r.p.m. on the other hand; the highest actual performance rate (after modification) was 0.088 $\mathrm{fed} / \mathrm{h}$ recorded at the disk rotational speed 9000 rpm with plant density 6000 plant $/ \mathrm{m}^{2}$; and The highest performance efficiency was (85\%) recorded with the plant density $6000 \mathrm{plant} / \mathrm{m}^{2}$ at the disk speed $9000 \mathrm{rpm}$. As well as, the energy requirements for the solar powered machine ranged between 4.431 to $4.454 \mathrm{kw}$.h/fed. While it was ranged between 15.11 to $19.6 \mathrm{kw}$.h/fed for the gasoline powered machine. The operating cost was 4.076 L.E/h. and 53.5 L.E/fed; by using the solar powered machine; that reduce the total operating cost L.E/h by $80 \%$ compared with the gasoline powered machine.

Keywords: Electric Hand held; disk mower; solar energy; DC motor; and mechanical properties of alfalfa 


\section{1- INTRODUCTION}

Egypt suffers from a severe energy shortage, especially of electricity. The installed generation capacity falls short of meeting peak demand, leading to frequent blackouts and supply curtailments to industry. The problem is further intensified by rapid growth of domestic demand, which is expected to climb at a rate of 5-6\% annually over the next years. Even in the most optimistic scenario, at least $15 \%$ of energy demand will not be met by 2022, Al-Ayouty and Abd El-Raouf (2015). At its peak, energy demand in Egypt is currently around $30,000 \mathrm{MW}$ with a supply of a little over $26,000 \mathrm{MW}$, leaving an energy deficit of around 4,000 MW. This deficit creates the frequent power cuts, which Egypt suffers from during peak demand, especially in the hot summer months. The sustained increase in population that is predicted to continue at around $1.6 \%$ per year is the most dominating, EERAAR (2014). Egypt's petroleum and other liquids production averaged 666,000 barrels per day (b/d) in 2017. Total crude oil consumption increased by approximately $16 \%$ since 2007 , averaging $802,000 \mathrm{~b} / \mathrm{d}$ in 2017 , and it is expected to continue growing, even when accounting for the phasing out of subsidies. The bill of subsidies petroleum products and natural gas about 125 billion pounds for the fiscal year 2017/2018. Egypt, like most countries in the world, at present relies more heavily on non-renewable resources than renewables; more than $90 \%$ of its power supply is generated from fossil fuels. However, Egypt possesses an abundance of land, a sunny climate, and high wind speeds, making it a prime location for generating renewable energy. The government of Egypt is determined to capitalize on these resources to achieve its target of diversifying its energy mix; it aims to generate $20 \%$ of its power from renewable sources by year of 2022, with wind providing $12 \%(7.2 \mathrm{GW})$, hydropower $5.8 \%$, and solar $2.2 \%$. Solar energy will generate $3.5 \mathrm{GW}$ by 2027, including 2.8 GW of photovoltaic and 700 $\mathrm{MW}$ of concentrated solar power. The percentage of power generated from renewable sources is targeted to increase further to $37 \%$ by 2035 . Energy consumption in farming is highly reliant on diesel, both for direct use for equipment (i.e. pumps), or the generation of electricity. Agricultural processes and applications require energy, in the form of electrical and mechanical power for many uses including land preparation, seeding, irrigation, delivery of pesticides, and harvesting among others. The agriculture sector represents $6 \%$ of the total energy consumption in Egypt, RCREEE (2012). About 2139 Kilo tonne of Oil Equivalent "ktoe" of fuel were consumed mostly in the form of diesel, compared to 416 ktoe of electricity in 2016. From 2007 to 2017 the spending on energy in agriculture averaged 7.6 Billion EGP/year which is approximately $15 \%$ of net contribution of the sector to the economy, Egyptera (2016). Ensuring sustainable, secure, stable, and competitive energy supply is of major importance to the sector, Egyptera (2014). Photo voltaic "PV" farming can be defined as the utilization of PV energy applications within the agricultural value chain. PV systems have multiple uses in the farming. It can be used to power equipment such as pumps, to produce electric power for lighting, for spraying pesticides, powering shredders, in addition to water heating and produce drying. When PV technology is deployed with a user-centric application and business model it can provide the agriculture sector with cost competitive, reliable, easy to use, sustainable energy, RCREEE (2016). The agriculture was an early adopter of solar energy as a remote energy source, and many of those initial applications are still cost effective today due to low maintenance costs and the high cost of extending electricity to remote locations, Xiarchos and Vick (2011). Using the sun to dry crops and grain is one of the oldest and mostly widely used applications of solar energy. Using solar energy eliminates down time by frequent trips to the gas station for fillips and danger associated with gasoline spillage, Taniola et al (2014). The advantages of using solar PV pump compared with diesel and gasoline pump were unattended operation; low maintenance; easy installation, long life and environmentally friendly (no noise and no fume pollution). While disadvantages were high capital costs; and repair often require skilled technicians, Abu-Aligah (2011). Rotary mowers are the most widespread and versatile machines for home lawn maintenance. Gasoline rotary mowers are usually chosen for larger home lawns, while electric rotary mowers are usually chosen for smaller home lawns. Electric rotary mowers are supplied with electricity using a cord or a battery. In fact, battery powered rotary mowers are still not in widespread use since their cost is higher compared to cord-supplied models and the surface they can cover usually ranges from 500 to $1000 \mathrm{~m}^{2}$, Grossi et al (2016). Sealed lead batteries were suitable power source for lawn mowers, but if their discharge voltage dropped below a certain limit then they could not be recharged, or normal life of the battery was 
drastically reduced. The point at which it happened depended to some extent on rate of the battery which further depended on the condition of its use. Current sensing devices had been used to disable the battery if the current was drawn above the certain limit from the battery. The objective was to control power supply system for battery powered machines. Using a control system for monitoring the voltage discharge levels of the battery and to disable it, improved the battery life and the efficiency, McNair et al (1996). The hypothesis of this study is that, success of operation any agricultural machine powered by solar energy means the possibility of saving fuel consumed to operate approximately 315.5 thousand machines used in Egypt for various agricultural applications, CAPMAS (2015). As well as reduce the greenhouse gases and its negative environmental impact The overall objective of the current research was to convert a hand held gasoline disk mower into an electric solar powered mower by replacing the gasoline engine with an electric DC motor that runs from a 12 volt battery; this battery will be charged using a photovoltaic solar panel.

\section{2- MATERIALS AND METHODS}

\subsection{Materials}

\subsubsection{Experimental location}

All Experiments were conducted at El-Dakhla, New Valley, Egypt. The latitude and longitude of the experiment site are $25^{\circ} 15^{\prime} 25.2^{\prime \prime} \mathrm{N}, 2^{\circ} 30^{\prime}$ 01.2" $\mathrm{E}$. Based on the obtained data taken from Meteorological stations, El-Dakhla, New Valley, Egypt, the averages of sunshine duration " $n$ "; length of the daylight " $\mathrm{N}$ "; extraterrestrial solar radiation $\left(R_{a}\right)$ and solar radiation $\left(R_{s}\right)$ were 9.412.4 h; 10.60-13.56 h; 22.75-40.49 MJ m-2 day-1 and 16.53-29.65 MJ m-2 day-1, respectively. These values related to the study area in the period from August, 2016 to February, 2018. Actual Solar radiation $\left(R_{s}\right)$ estimated by using the following equation.

$$
R_{s}=\left(0.25+\left(0.5 \frac{n}{N}\right)\right) R_{a}
$$

2.1.2. The gasoline-powered disk mower (before modification)

The gasoline-powered disk mower used in this study, was a CG 520 (Al-Nakip model), made in
China. The disk mower was hand held type that can be equipping the attached shawl band. The working width was $50 \mathrm{~cm}$. Cutting height was adjustable from 1.4 to $7.6 \mathrm{~cm}$. The power generator was a one stroke gasoline engine with an output of $1.46 \mathrm{~kW}$, with an overhead camshaft and a displacement of $51.7 \mathrm{CC}$. Main parts of the gasoline powered disk mower illustrated in Figure 1 and the specification of the gasoline-powered disk mower presented in Table $\mathbf{1 .}$

\subsubsection{Modification concept}

Based on the general principle of cutting operation with disk mower; the working principle of solar disk mower is depend on a panel arrangement subjected to solar radiation with high intensity easily from the sun. The solar panel converts solar energy into electrical energy. This electrical energy is stored in batteries by using a solar charger. The main function of the solar charger is to increase the current from the panel while batteries are charging. The motor is connected to battery through connecting wires. Between these mechanical circuit breaker switch is provided to starts and stops the working of the motor. From this motor power transmits to the mechanism and this makes the blade to rotate on the shaft this makes to cut the grass.

\subsubsection{Main components for the proposed modification}

The Solar powered disk mower system passed through three stages:

First stage: Generating electric power from PV cells.

Second stage: charging the battery

Third stage: Converting electric energy into mechanical power using DC motor.

Fig. (2) shows the system, which is designed to charge battery then take battery to drive the DC motor. The system consisted of 4 elements, i.e.

1. Photovoltaic generator 2. Battery charger 3. Battery 4. DC powered motor.

\subsubsection{Gasoline-powered disk mower (after modification)}

To facilitate operating the gasoline powered disk mower with electric energy taken from a solar station, the following modifications was performed. 


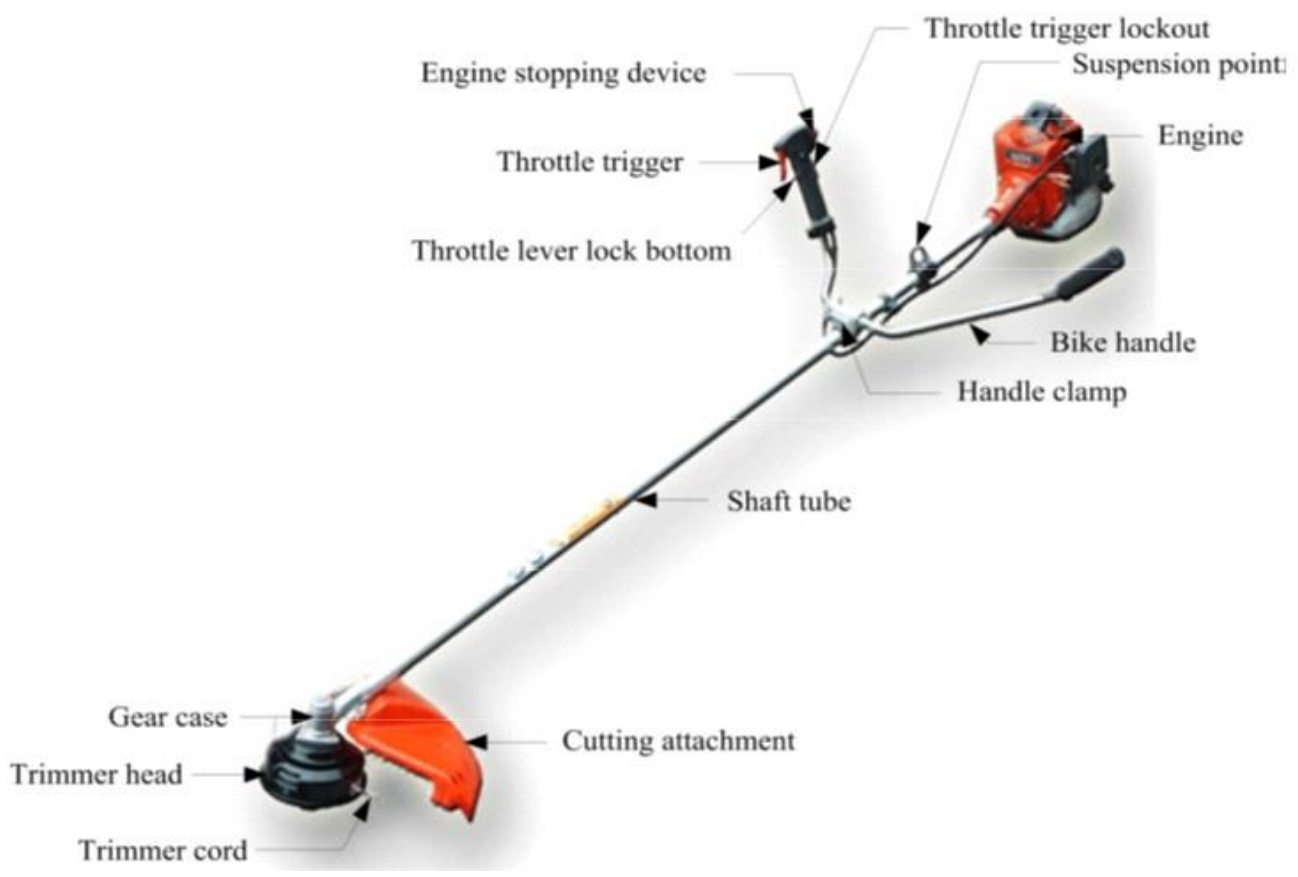

Fig. 1. The main parts of the gasoline-powered disk mower

Table 1. Specification of the gasoline-powered disk mower

\begin{tabular}{|c|c|}
\hline Property & Description \\
\hline Product item & HJ-CG520 \\
Engine drive & Air-cooling, two-stroke, single cylinder gasoline \\
Displacement & $51.7 \mathrm{CC}$ \\
Engine power & $1.46 \mathrm{kw} / 6500 \sim 9000 \mathrm{r} / \mathrm{min}$ \\
Idle speed & $2800 \sim 3200 \mathrm{r} / \mathrm{min}$ \\
Fuel tank capacity & $1200 \mathrm{ml}$ \\
Fuel/oil mixture ratio & $25: 1$ \\
Working pole diameter & $26 \mathrm{~mm} 28 \mathrm{~mm}$ \\
Engine mass & $4.7 \mathrm{~kg}$ \\
Machine mass & $7.8 \mathrm{~kg}$ \\
Product dimension & $1850 * 520 * 400 \mathrm{~mm}$ \\
\hline
\end{tabular}

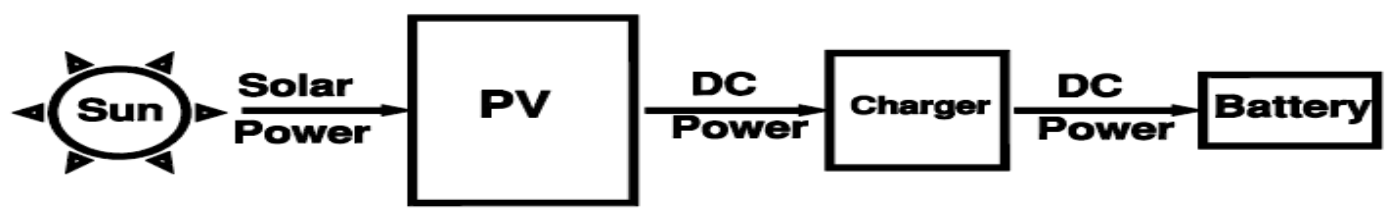

Fig. 2. The main components of charge battery system. 
a) Replacement the gasoline motor with Dc motor

The disk cutter of the gasoline powered disk mower is generally driven by an internal combustion engine. It is replaced by a permanent magnet DC motor of a treadmill to be a power source for the proposed disk mower. Taken the manufacturing cost and compact size into consideration, a permanent magnet and brush type DC motor is adopted. The magnetic intensity of the selected DC motor is constant. So that, the rotation speed of the driven DC motor or the blade of the disk mower should be controlled by the generated magnetic field intensity in the rotor or armature of the DC motor. The complexity of the speed controller for the permanent magnet DC motor is generally easier and cheaper than the other types. So that it is adopted as the driven motor of the electric type disk mower. The selected DC motor technical specifications voltage, maximum speed, maximum power and weight were $12 \mathrm{~V}, 9000 \mathrm{rpm}, 250 \mathrm{~W}$ and $0.420 \mathrm{~N}$ respectively. DC motor was installed firstly at the rear end of the handle.at the same position of the gasoline motor; Fig. (3); nevertheless the cutting performance of the machine was unacceptable, so that DC motor was installed directly with the cutting disc. The original drive shaft of the selected DC motor was replaced with another shaft $12 \mathrm{~mm}$ diameter to be suited with the cutting disc diameter as presented in Fig. (4).

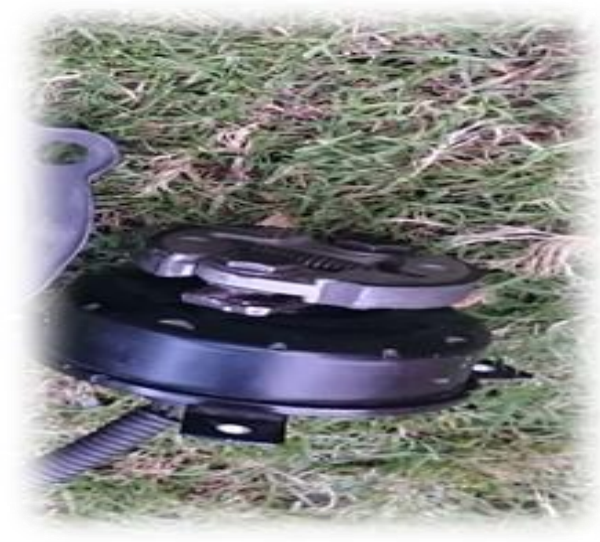

Fig. 3. DC motor installed in the rear end of machine

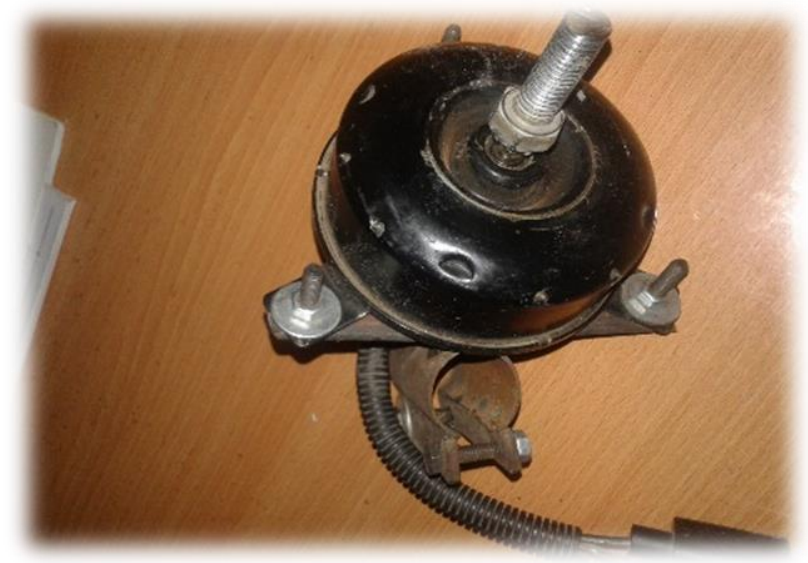

Fig. 4. DC motor installed directly with cutter disk by modified drive shaft

\section{b) Photovoltaic solar station}

The solar energy station that used in this study was 260 panels, have been built since 2009 to serve cultivation area of $100 \mathrm{fed}$., with a maximum power outlet by $65 \mathrm{~kW}$, one panel only from this plant was used to charge the battery of the solarpowered disk mower. The panel mod was SOLAR WORLD; model SW 275 W Polo crystalline. PV array were installed with tilt angle range 27 to $30^{\circ}$ 잉 from the horizontal, this module spend one hour to charge the battery during the day light hours. The technical specifications of the PV modules was that: Rated maximum power $\mathrm{P}_{\max } 275 \mathrm{~W}$; current at $P_{\max } 6.61 \mathrm{~A}$; voltage at $P_{\max }$ " $V_{m p}$ " $31 \mathrm{~V}$; short circuit current Isc, $9.58 \mathrm{~A}$; open circuit voltage Voc $39.4 \mathrm{~V}$ and dimension were, $1330 \times 992 \times 40 \mathrm{~mm}$.

\section{c) Battery charger}

The power charge regulator is also known as charge controller, voltage regulator, charge/discharge controller or load controller. The regulator sits between the array of panels, the batteries, and the equipment or loads. By monitoring the voltage of battery, the regulator prevents overcharging or over discharging. Regulators used in solar applications should be connected in series (never be connected in parallel), in order to protect the battery from gasification. They disconnect the array of panels from the battery to avoid overcharging, and they disconnect the battery from the load to avoid over discharging. The connection and disconnection is done by means of switches which can be of two types: electromechanical (relays) or solid state 
(bipolar transistor). The most modern regulators are also able to automatically disconnect the panels during the night to avoid discharging of the battery. They can also periodically overcharge the battery to improve their life, and they may use a mechanism known as pulse width modulation (PWM). Table (2) the general specifications of the charge controller.

Table 2. Technical specifications of the battery charger

\begin{tabular}{|c|c|}
\hline Property & Description \\
\hline Category & ST-W1220 \\
Adapt to battery voltage & $12 \mathrm{~V} / 24 \mathrm{~V}$ Battery \\
Voltage identification & Battery voltage $<17 \mathrm{~V}:$ \\
$12 \mathrm{~V}$ system \\
Battery voltage $>18 \mathrm{~V}: 24$ \\
$\mathrm{~V}$ system \\
$20 \mathrm{~A}$ \\
Maximum Current \\
output \\
Solar panels Power \\
Size & $12 \mathrm{~V}(180 \mathrm{~W}) \& 24 \mathrm{~V}(360$ \\
$\mathrm{W})$ \\
$12.8^{*} 8.5^{\star} 3 \mathrm{~cm}$ \\
\hline
\end{tabular}

\section{d) Battery}

The selected battery was led acid $12 \mathrm{~V} ; 20 \mathrm{Ah}$ and its mass about $1.4 \mathrm{~kg}$.

\subsubsection{Experimental plant}

Alfalfa "Medicago Sativa" was used for all series of experiments, to test the disk mower before and after the proposed development. Alfalfa stems were cut at $10 \%$ bloom stage from the most common variety of alfalfa crop (Giza 1) and it bears 63 leaves.

\subsection{Methods}

\subsubsection{Preliminary tests}

The overall objective of the preliminary test was to obtain the required data to perform the proposed modification (replacement of the DC motor instead of gasoline engine) for selecting the main components of the system which were (DC Motor; battery; charger). These tests include the following:

a- Morphological properties of alfalfa.

b- Alfalfa cutting force.

c- The applied torque on the cutter disk shaft (after modification).

d- Testing the state of charge curve "S.O.C" of the selected battery.

\subsubsection{Final field test}

The field tests were performed in plot dimensions as one meter width and 6 meter length. The modified solar powered electric disk mower was tested and evaluated compared with the gasoline powered machine according to the following:

\subsubsection{Studied parameters}

1- Plant density: alfalfa stems have three density levels, low $\left(<6000 \mathrm{stalk} / \mathrm{m}^{2}\right)$ medium $(6000-9000$ stalk $\left./ \mathrm{m}^{2}\right)$ and high $(\geq 12000$ stalk/m²).

2- Cutter disk rotational speed:

a- For the gasoline powered machine (1000 and 3600 r.p.m.) before modification.

b- For electric powered machine (3600; 6000 and 9000 r.p.m.) after modification .

\subsubsection{Machine performance tests}

To determine the performance rate and efficiencies for the hand held disk mower machines before and after modification the following equations were used according to Bello et al (2015).

- Machine performance rate, PR (fed/h.):

$P R=$ Total area effectively mowed at full battery charged / time; (fed/h)

- Cutting efficiency, ncutting (\%).

$$
\begin{gathered}
\begin{array}{c}
\text { ycutting } \\
\text { Total number of smoothly cut plant }
\end{array} \\
\begin{array}{c}
\text { Total number of plant population - } \\
\text { total number of rough cut }
\end{array}
\end{gathered}
$$

- Machine performance efficiency, nper (\%)

$$
\eta p e r=\frac{\text { plant smoothly cut per square area }}{\text { plant roughly cut per square area }} \times 100 \%-(3)
$$

\subsubsection{Fuel consumption}

The rate of fuel consumption of the gasoline powered machine was calculated as quantity per unit time, as shown in the following formula:

$$
\text { C.F. }=(f / t) \times 3.6, I / h
$$

Where:

C.F. = fuel consumption, $\mathrm{l} / \mathrm{h} ; \mathrm{f}=$ volume of fuel consumption, $\mathrm{cm}^{3}$ and $\mathrm{t}=$ time, $\mathrm{s}$. 


\section{Specific energy requirements}

The specific energy requirement can be calculated as following:

$$
\begin{gathered}
\begin{array}{c}
\text { Energy requirements }= \\
\text { Engine power }(\mathrm{kW})
\end{array} \\
\text { Effective field capacity }(\mathrm{fed} / \mathrm{h})
\end{gathered}(\mathrm{kW} . \mathrm{h} / \mathrm{fed}) \text {------ }(5)
$$

The following formula was used to estimate the engine power, Embaby (1985).

$$
\begin{aligned}
& E . P .=(F . C(1 / 60 \times 60)) \rho . F \times L . C . V X 427 \times \eta_{t h} \\
& X \eta_{m} X 1 / 75 \times 1 / 136, k W .
\end{aligned}
$$

Where: $F . C=$ Fuel consumption, $\mathrm{I} / \mathrm{h} ; \rho . \mathrm{F}=$ Density of fuel, $\mathrm{kg} / \mathrm{l}$ (for solar $=0.85$ );

L.C.V = the lower caloric value of fuel $(\mathrm{kcal} / \mathrm{kg}$ ) (average of L.C.V of solar is $10000 \mathrm{k}$. cal $/ \mathrm{kg}$ ); $\eta_{\text {th }}=$ Thermal efficiency of the engine, (Consider being about $35 \%$ for the diesel engine); 427= Thermomechanical equivalent, $\mathrm{kg}-\mathrm{m} / \mathrm{kcal} ; \eta_{\mathrm{m}}=$ Mechanical efficiency of the engine (Consider being about $80 \%$ for the gasoline engine) and

Engine power = 3.16 F.C, $k W / h$. (7)

\subsection{Test apparatus / instrumentation}

Type HANDSKIT DT-9205A Multi meter was used to measure the amber and the voltage for the battery before mowing and recorded the amber consumption at mowing for motor and finally measure the volt of the battery. Shear force meter model Shimpo FGE-50X Dart FGE-X Series Digital Force Gauge - $50 \mathrm{lb}$. Its capacity and resolution were $200 \mathrm{~N}$ and $0.1 \mathrm{~N}$. Tachometer model VICTOR DM6234P + was used to measure the rotational speed. As well as tape with 10-meter and stopwatch used to measure the dimensions of cutting area and operating time. The Caliper used to measure the diameter and other alfalfa stem dimensions. The digital Balance with accuracy of 0.1 gram was used for all treatment conditions.

\section{3- RESULTS AND DISCUSSIONS}

\section{A- Prelminary tests}

\section{1- Alfalfa morphological properties}

The morphological properties of alfalfa were presented in Table 3.
Table 3. Morphological properties of alfalfa plant.

\begin{tabular}{|l|c|c|c|}
\hline \multicolumn{1}{|c|}{ Property } & Min. & Average & Max. \\
\hline Stalk height; $\mathrm{cm}$. & 60 & 75 & 90 \\
Stalk diameter; mm. & 1.9 & 3.75 & 4 \\
Plant density; Plant/m² & \multicolumn{3}{|c}{$6000-12200$} \\
Moisture contents; \% & \multicolumn{3}{|c|}{$79-89$} \\
Plant yield; ton/fed & \multicolumn{2}{|c|}{$8-14$} \\
\hline
\end{tabular}

\section{2- Cutting force}

Fig. (5) shows the relationship between stalk diameters; "mm" and cutting force; "N". It is clear that, there was a direct relationship between cutting force " $F_{\text {cut }}$ and plant diameter " $d$ ". this relation between stalk diameter; and cutting force could be expressed by the following equation: $F_{\text {cut }}$ $=23.743 \mathrm{~d}+36.47$. It means that, with increasing the diameter of alfalfa plant the required cutting force increased. The lowest value of the cuting force was $80.5 \mathrm{~N}$ that recorded with stalk diameter $1.9 \mathrm{~mm}$. While the highest value of the cutting force was $130 \mathrm{~N}$, recorded with Alfalfa stalk diameter $1.4 \mathrm{~mm}$.

\section{3- The applied torque on the cutting disk shaft} (after modification).

Fig. (6) illustrated the relationship between the cutting disk speed and the applied torque at two positions of the DC motor" T1 and T2". It is clear that; there was an inverse relation between the rotational speed and applied torque on the cutting disk shaft at the two positions of the DC motor; where the applied torque decrease with increase the rotational speed of the shaft. On the other hand; the recorded maximum and minimum values of the applied torque on the cutting disk shaft when the DC motor installed at the same position of the gasoline engine "T1" were 0.48969 and 0.19588 N.m., these value less than the required; so the cutting performance was therefore unacceptable. While the recorded values of the applied torque on the cutting disk shaft when the DC motor installed directly with the cutting disk "T2" were 0.6366 and 0.2546 N.m.

\section{4- State of charge for the selected battery}

Fig. (7) illustrated the state of charge; S.O.C.\% curve for the selected battery at DC motor pulled 15 amper. It was clearly that the battery charging level was $100 \%$ "from full charging" when the terminal voltage was 14 Volt. While it was $20 \%$ 


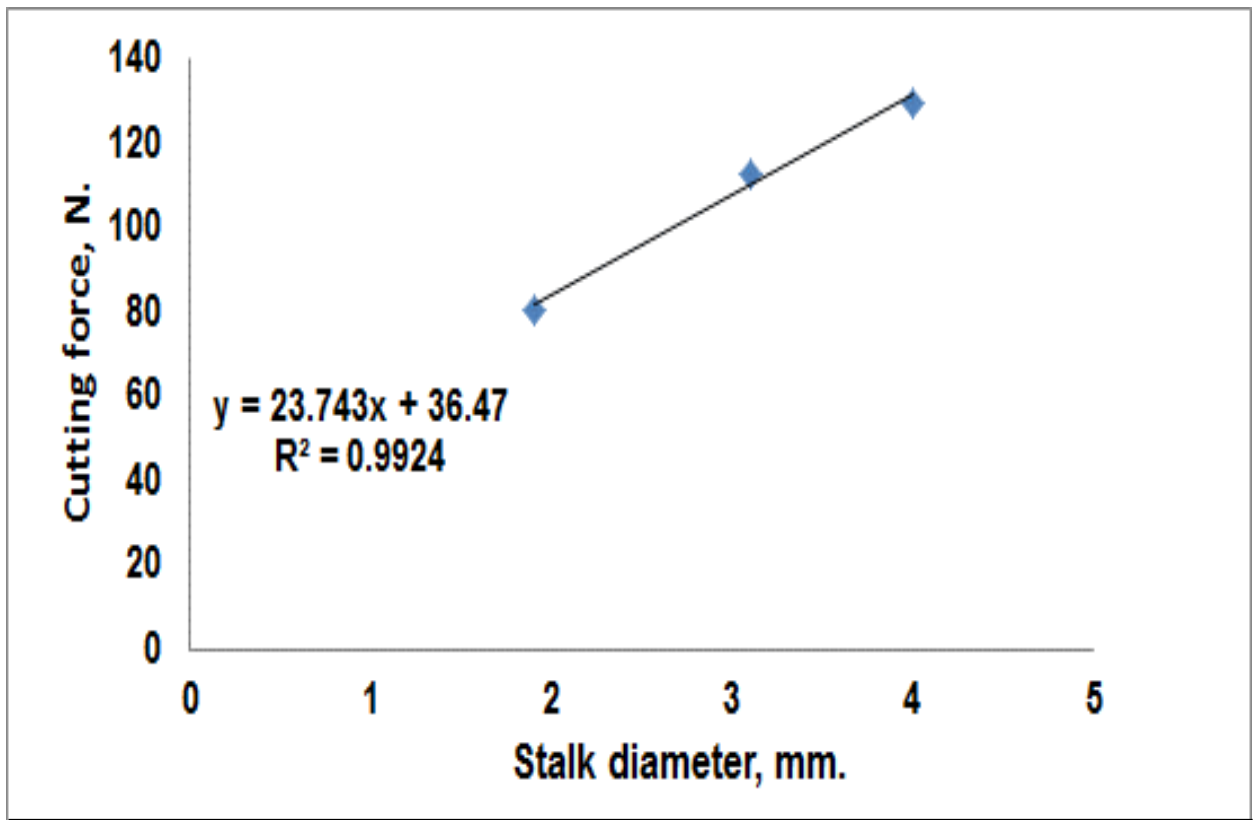

Fig. 5. The relationship between alfalfa stalk diameter and cutting force, $\mathrm{N}$.

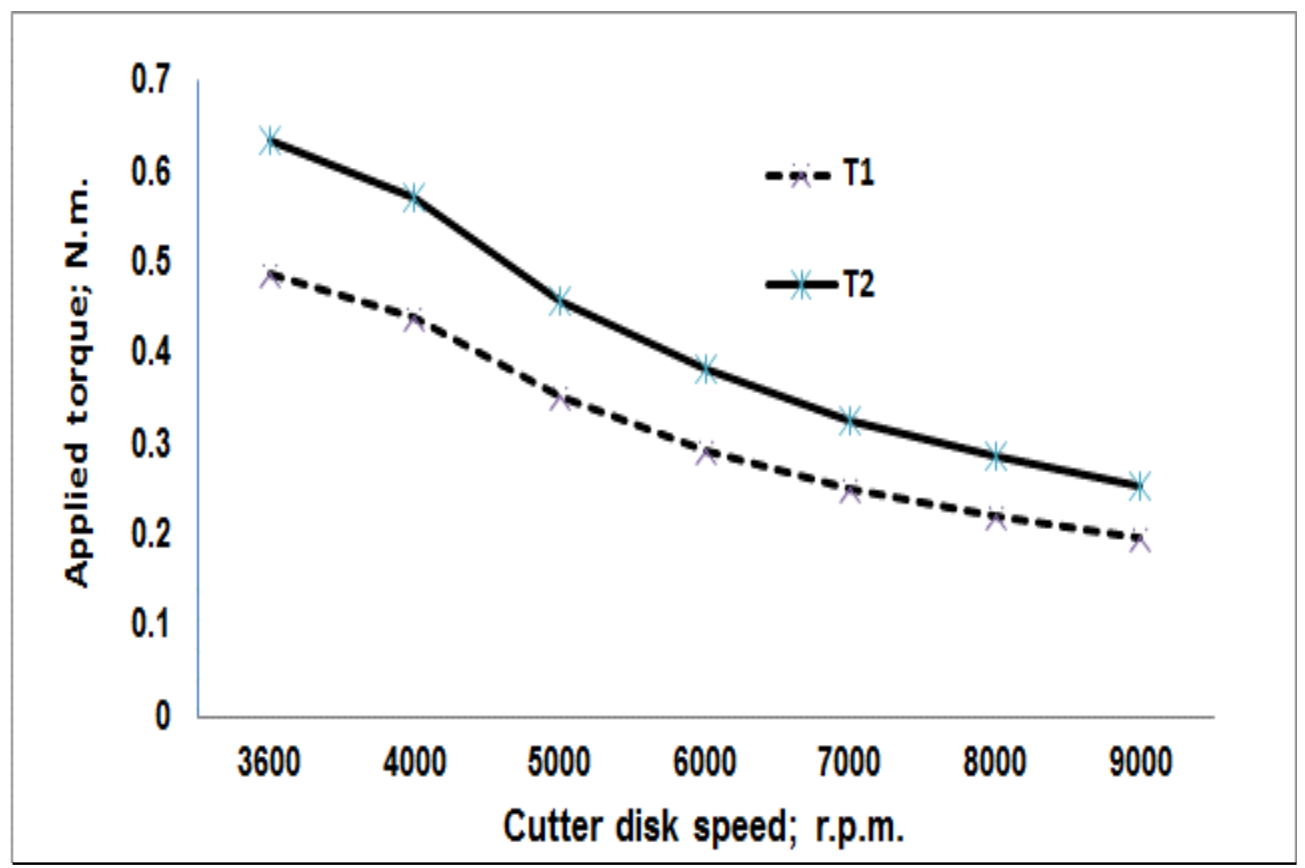

Fig. 6. The relationship between cutter disk speed and applied torque at two positions of DC motor 


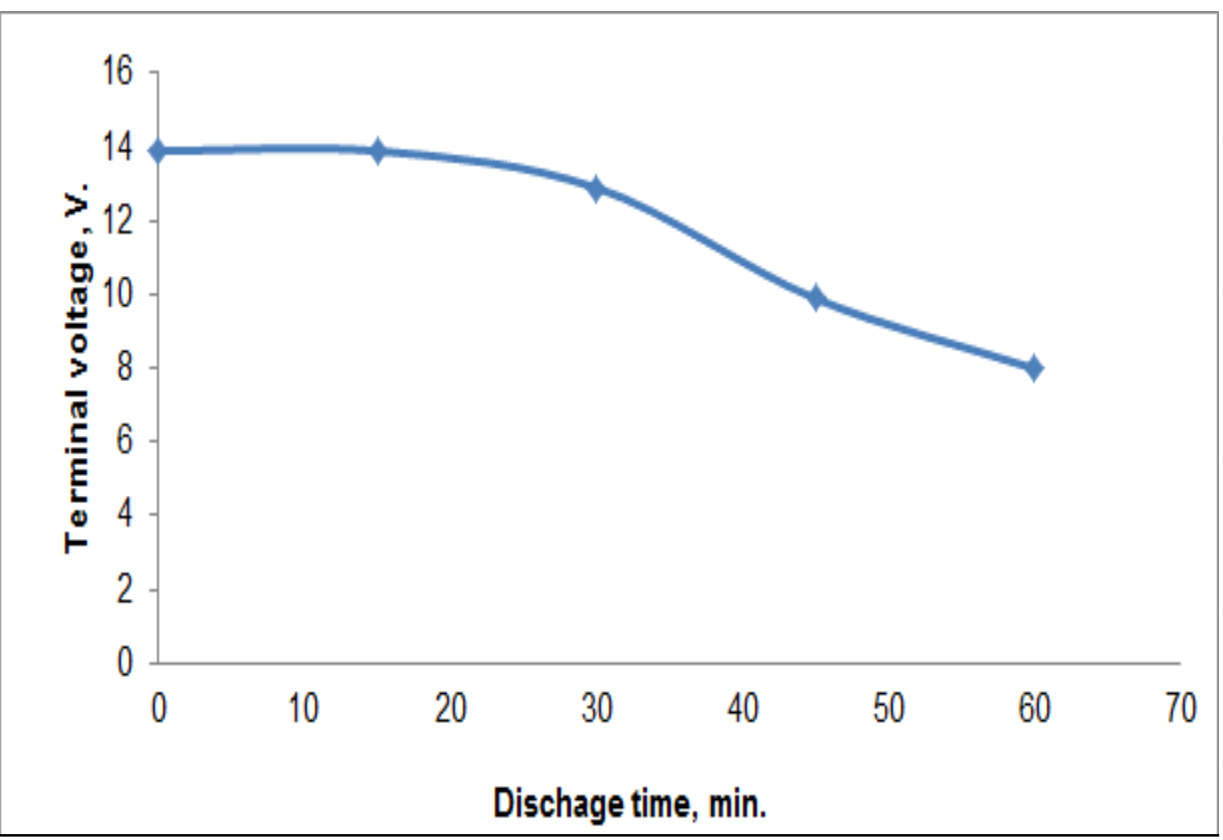

Fig. 7. State of charge "S.O.C" for the selected battery at motor pulled 15 Ampere

"from full discharging" when the voltage was 8 Volt. This test was occurred to define the selected battery current limits available for mowing about one hour, with 15 amper. After one houre mowing the terminal voltage dropes of abruptly, indicating a fully dischargeed battery.

Fig. (8) shows the applied current charge when the operating condition from stand by status to cutting lawn. It was clear that the current flactuated between the maximum limits at the active stroke and gradiually decreased to the minmum limit at the drawn down stroke. The current flactuated from 4 to12 $\mathrm{A}$, at cutting process.

\section{B- Field test}

\section{1- Performance rate}

Fig. (9) presented that the relasionship between the Alfalfa plant density on performance rate at different cutting disk speed " $3600 ; 6000$ and 9000 rpm". It was clear that the highest perfomance rate was $(0.088 \mathrm{fed} / \mathrm{h})$ recorded with the lowest plant density less than 6000 plant $/ \mathrm{m}^{2}$ when the disk rotational speed was $9000 \mathrm{rpm}$. While the lowest performance rate was $(0.044$ fed/h) recorded at the highest density $\geq 12000$ plant $/ \mathrm{m}^{2}$ when the disk rotational speed was 6000 $\mathrm{rpm}$; it means that the performance rate was directly proportional to the disk speed and reversaly proportional to the plant density. The maximum performance rate was $0.209 \mathrm{fed} / \mathrm{h}$ for the gasoline mower (before modified).

\section{2- Performance efficiency}

Fig. (10) presented the effect of alfalfa plant density (and disk speed "3600; 6000 and 9000 rpm" on the machine performance efficiency. It was clear that; the highest perfomance efficiency was $(37.26 \%)$ recorded at the lowest plant density less than 6000 plant $/ \mathrm{m}^{2}$ when the disk speed was 9000 rpm. While the lowest performance efficiency was $(18.63 \%)$ recorded at the highest density more than 12000 plant $/ \mathrm{m}^{2}$ when the disk speed was $6000 \mathrm{rpm}$; it means that the performance efficiency was directly proportional to the disk speed and reversaly proportional to the plant density.

\section{3- Cutting efficiency}

Fig. (11) presented that the effect of Alfalfa plant density and cutting disk speed "3600; 6000 and 9000 rpm"on cutting machine efficiency. It was clear that the highest cutting efficiency was $85 \%$ recorded at the lowest plant density less than 6000 plant $/ \mathrm{m}^{2}$ when the disk speed was $9000 \mathrm{rpm}$. While the lowest cutting efficiency was $(60 \%)$ recorded at 
the density "less than 6000 and more than 12000" plant $/ \mathrm{m}^{2}$ when the disk speed was $3600 \mathrm{rpm}$; it means that, the cutting efficiency was incresed when the cutting disk speed increased from $3600-$ $6000 \mathrm{rpm}$, then the cutting efficiency was decreased when cutting speed incresead from $6000-9000 \mathrm{rpm}$. The maximum cutting efficiency percentage at cutting disk speed $6000 \mathrm{rpm}$ at different plant density. The cutting efficiency\% was decreased when plant density was increased different cutting disk speed.

\section{4- Energy consumption}

Fig. (12) illstrate the relationship between the plant density with the energy requirments at maximum cutting speed 9000 r.p.m as it was the ideal cutting speed for the hand held disk mower before and after modification. It was clear that, the energy consumption for the solar powered machine (after modification) was ranged from $4.431-4.545 \mathrm{kw} . \mathrm{h} / \mathrm{fed}$. Whiloe it was ranged between 15.11 to $19.6 \mathrm{kw} . \mathrm{h} / \mathrm{fed}$ for the gasoline powered machine (before modification). The energy consumption increased slightly when the plant density increased.

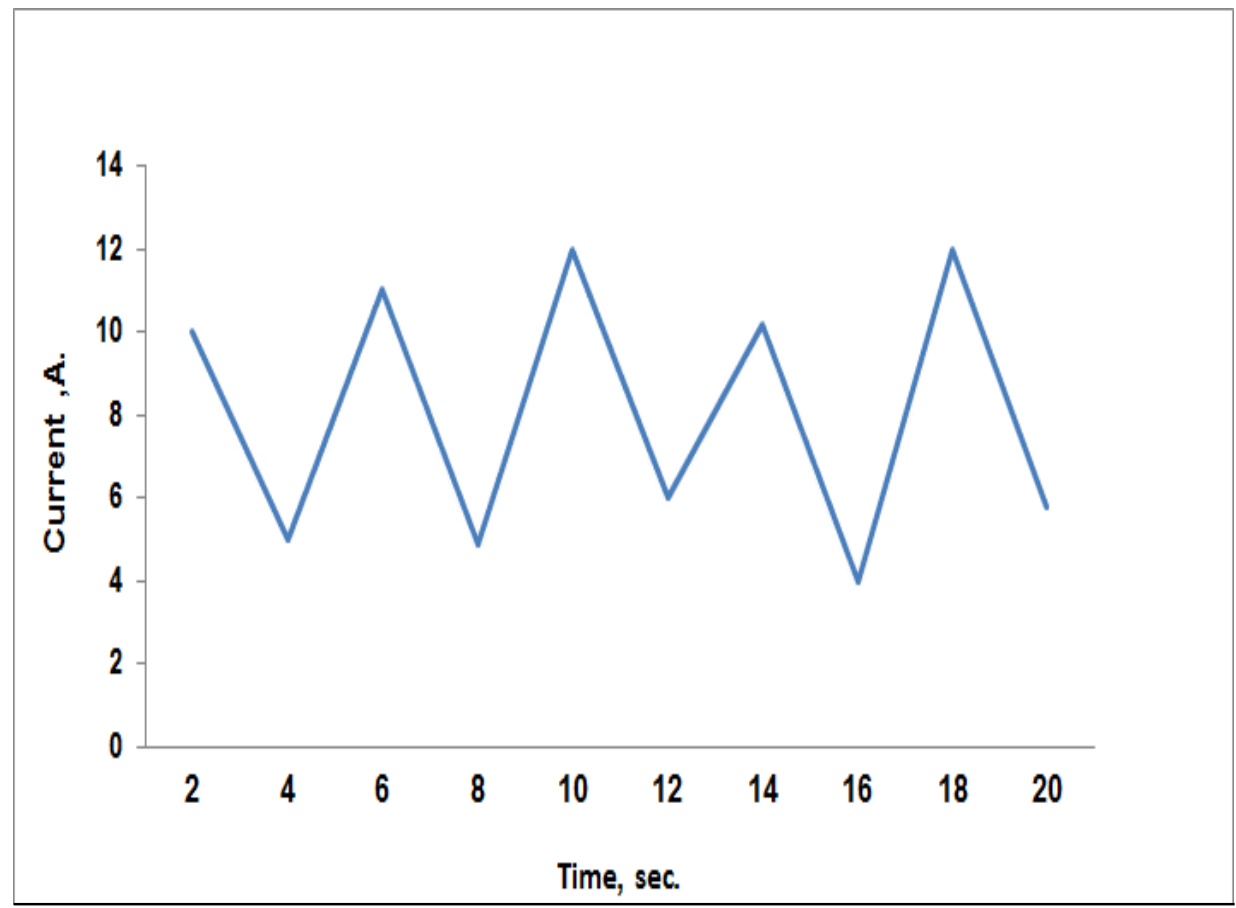

Fig. 8. The applied current change with the operating conditions from stand by status to cutting grass 


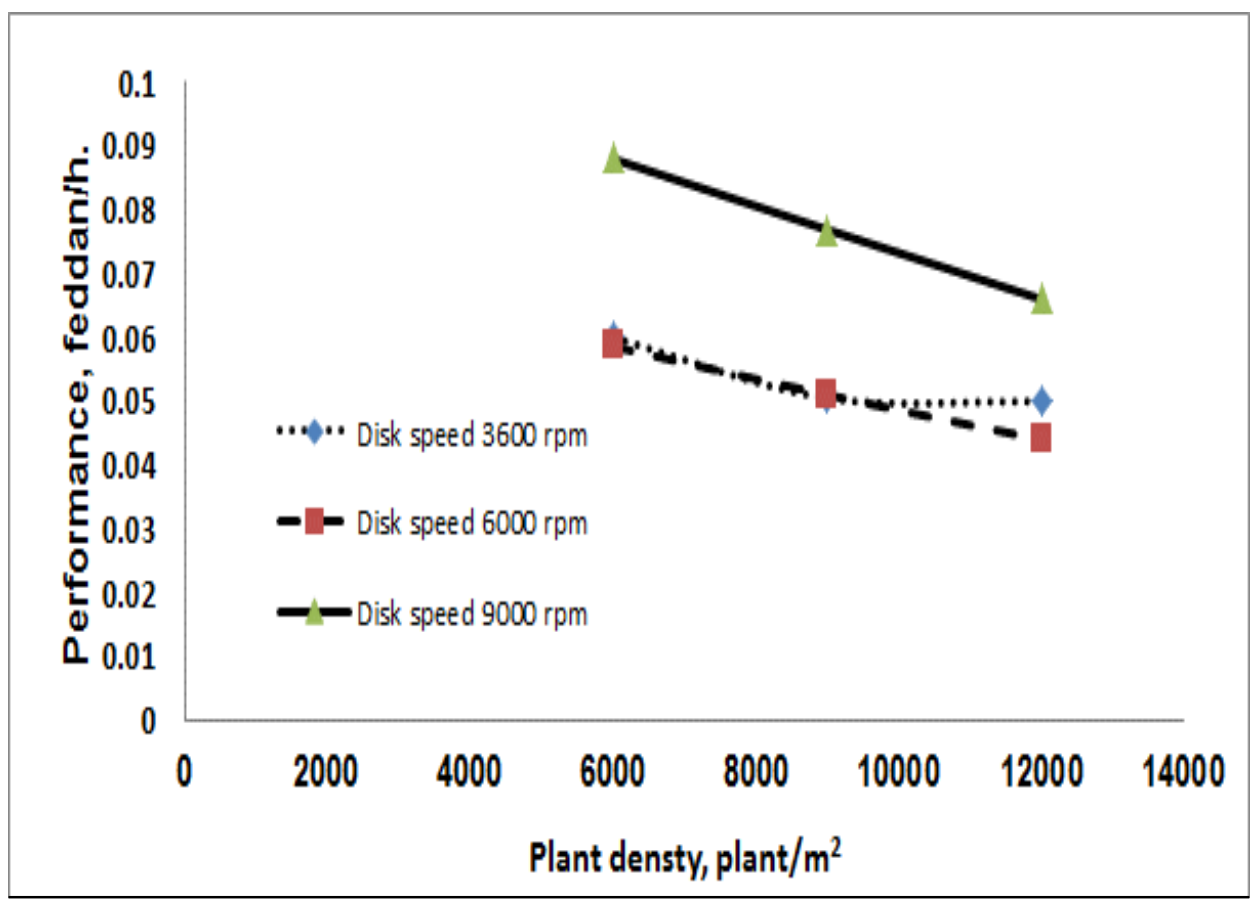

Fig. 9. Effect of plant density and cutter disk speed on machine performance rate

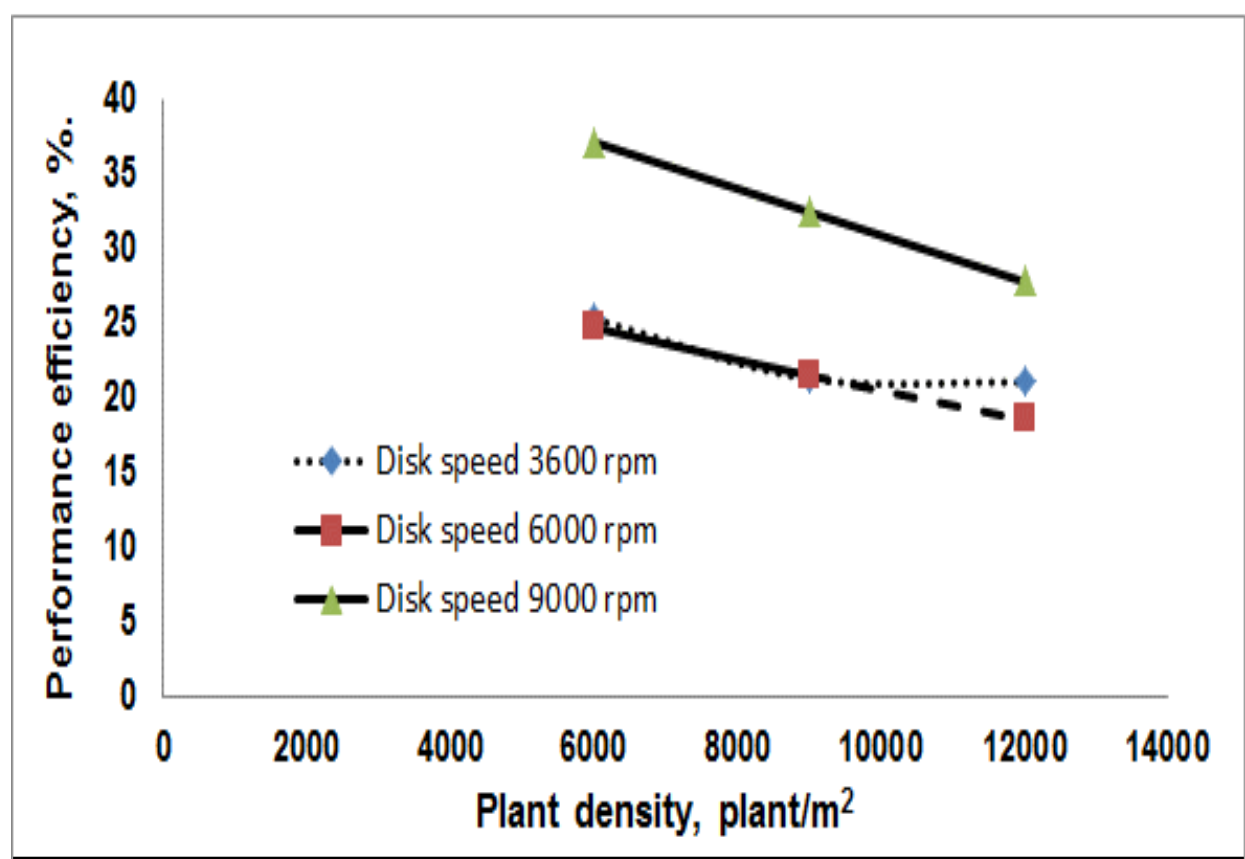

Fig. 10. Effect of plant density and cutter disk speed on machine performance efficency, \% 


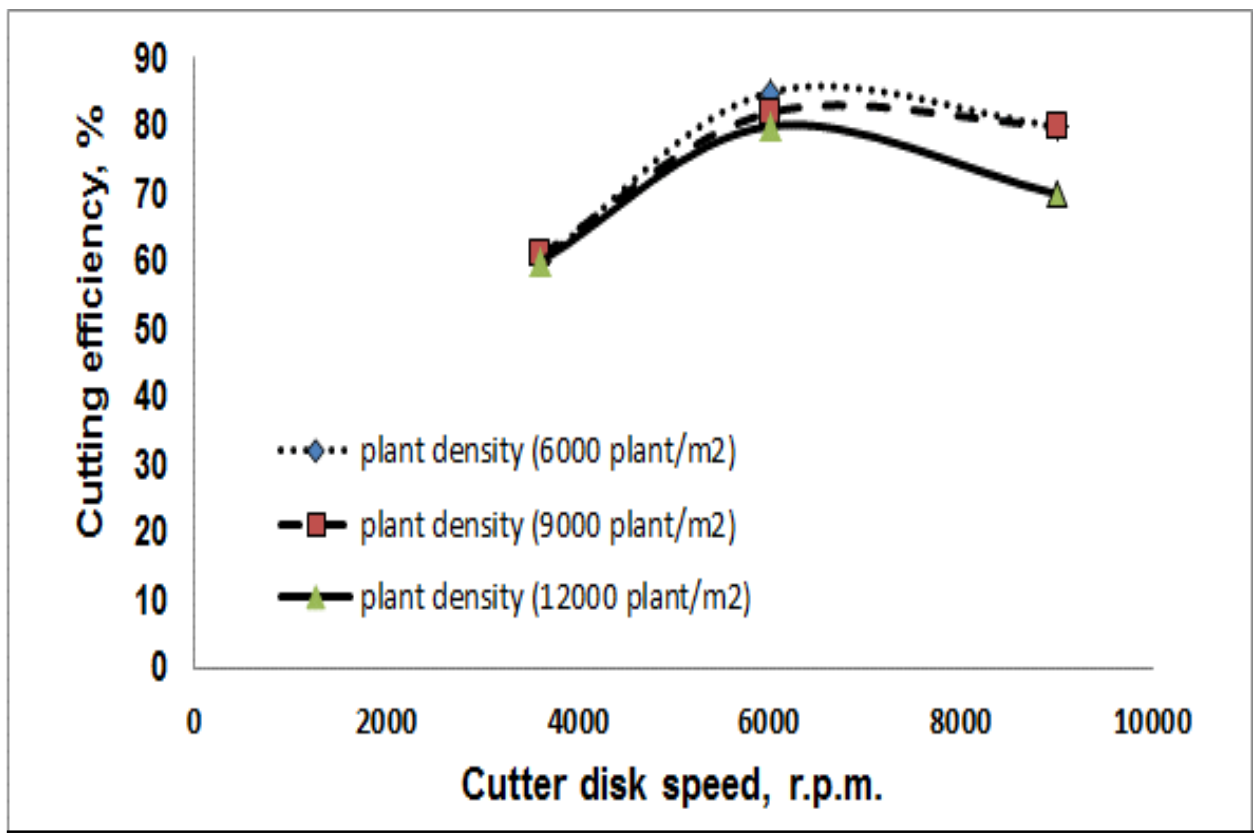

Fig. 11. The effect of cutter disk speed and plant density on cutting efficiency, \%

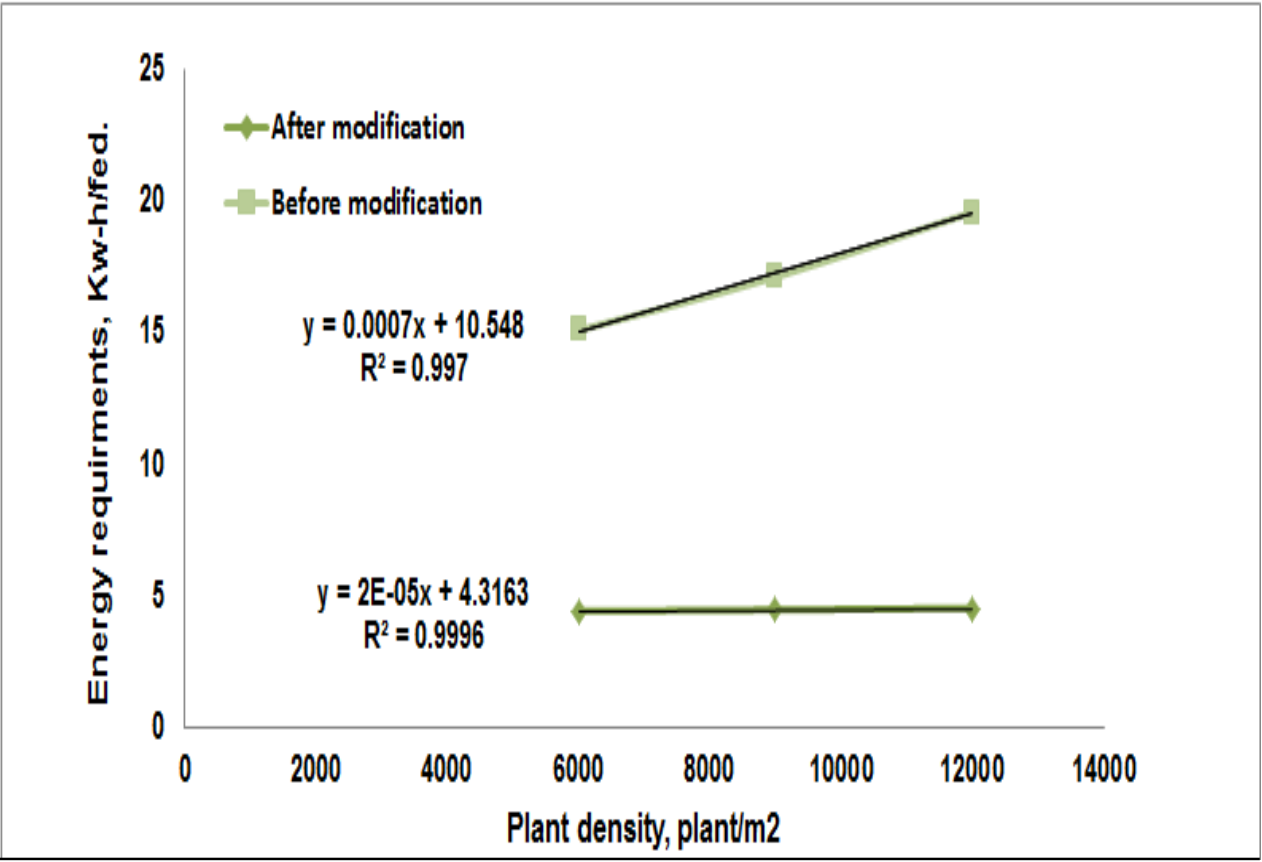

Fig. 12. The relationship between the plant dencity and energy requirments for gasoline and contered 


\section{4- CONCLUSION}

Our findings proved the possibility of converting a gasoline engine disk mower into solar powered disk mower exploiting solar energy as a source of power. Herein, it could be concluded that:

1- The solar powered hand-held disk mower was constructed with good and locally available materials. Its performance was satisfactory. The total production cost is quite affordable, compared with the gasoline powered machine; it was helpful for non-commercial use (home users) in maintaining and trimming the grass in gardens, home, or yards. Specially small home lawn less than $1000 \mathrm{~m}^{2}$

2- To ensure acceptable performance from the hand held solar mower; DC motor must install directly with the cutter disk.

3- Harnessing of solar energy was a viable solution to the energy crisis in Egypt.

4- Using DC motor instead of the gasoline engine will reduce the mass of the hand held disk mower from $12.5 \mathrm{~kg}$ to $9.6 \mathrm{~kg}$, which means easy maneuverability; more working hours and low level of labor fatigue.

5- Using solar power machine having much more advantages i.e. no fuel cost, no pollution and no fuel residue, less wear and tear because of less number of moving components and this can be operated by using solar energy which is vastly available.

6- The electrical circuit incorporating a charging device provides opportunity for continuous operation up to one hour at full battery charge.

7- The machine eliminated noise which is commonly associated with lawn mowers and brush cutters.

\section{RECOMMENDATIONS}

- Further research to improve performance rate by using most suitable DC motor.

- Having a facility of charging the batteries while the solar powered machine is in motion. So the same work can be operated in night time also, as there is a facility to charge these batteries in day light.

- Fabrication of the solar powered lawn mower.

- Further study on how to popularize usage of renewable energy should be done.

- Replacing solar power with the other Agriculture application will help to overcome the shortage on fossil fuels and electricity.
- Offering governmental support and subsidy for the solar equipment. The industries may encourage for producing these components in mass productions, so the cost of the system may come down. So in future it is expected to run all equipment's by using solar energy.

\section{6- REFERENCES}

Abu-Aligah M. 2011. Design of photovoltaic water pumping system and compare it with diesel powered pump. Jordan J. of Mechanical Industrial Engineering 5(3), 273-280.

Al-Ayouty I. and Abd EI Raouf N. 2015. Energy Security in Egypt. Cairo: ECES: The Egyptian Center for Economic Studies.

Bello R.S., Baruwa A. and Orisamuko F. 2015. Development and performance evaluation of a prototype electrically powered brush cutter. International Letters of Chemistry, Physics and Astronomy 58, 26-32.

Chikaire J., Nnadi F.N., Nwakwasi R.N., Anyoha N.O., Aja O.O., Onoh P.A. and Nwachukwu C.A. 2010. Solar energy applications for Agric., J. of Agric. and Veterinary Sci. 2, 85-62. www.cenresin.org.

EERAAR 2014. Egypt Electricity Regulatory Authority Annual Report 2013/14. 18 p., Accessed from: http://tinyurl.com/ ntnnqqj

Egyptera 2016. "Main Page." December 6, 2016. http://www.egyptera.org/en/.

Egyptera 2014. Renewable Energy - Feed-in-Tariff Projects' Regulations. Cairo: Egyptian Electric Utility for Consumer Protection and Regulatory Agency.

El Asmar Toufi C., Bardi Ugo. and Karłowski Jerzy 2009. Renewable energy multipurpose system for farmers (RAMseS) an environmental, technical and economic assessment with a comparison with a conventional thermodynamic vehicle. Polish J. of Agronomy 1, 15-18.

Embaby A.T. 1985. A comparison of the different mechanization systems for cereal crop production. M. Sc. Thesis, Agric. Eng. Dept., Faculty of Agric., Cairo Univ. Egypt.

Grossi N., Fontanelli M., Garramone E., Peruzzi A., Raffaelli M., Pirchio M., Martelloni L., Frasconi C., Caturegli L. and Gaetani M. 2016. Autonomous Mower Saves Energy and Improves Quality of Tall Fescue Lawn. HortTechnology, 26, 825-830. 
Regional Center for Renewable Energy and Energy Efficiency 2016. "Diesel to Solar Transformation Accelerating Achievement of SDG 7 on Sustainable Energy: Assessing Untapped SolarPotential in Existing Off-Grid Systems in the Arab Region." RCREEE.

Sujendran S. and Vanitha P. 2014. Smart Lawn Mower for Grass Trimming, IJSR, 3(3), 299303.

https://www.ijsr.net/archive/v3i3/MDIwMTMxMT E0.pdf

Tanimola O.A., Diabana P.D. and Bankde Y.O. 2014. Design and Development of a solar powered lawn mower. Int. J. of Scientific and Engineering Research, 5(6), 215-219.

Xiarchos I.M. and Vick B. 2011. Solar Energy Use in US Agriculture: Overview and Policy Issues. US Department of Agriculture, Office of the Chief Economist, Office of Energy Policy and New Uses.

Xuejuan Zi, Mao Li, Hanlin Zhou, Jun Tang, and Yimin Cai, 2017. Dynamics of shearing force and its correlations with chemical compositions and in vitro dry matter digestibility of stylo (Stylosanthes guianensis) stem, AsianAustralas J. Anim Sci., 30(12), 1718-1723. 


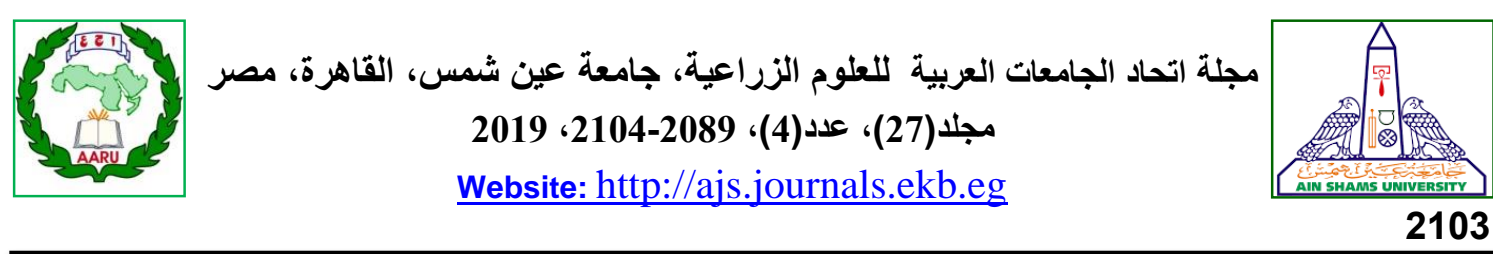

تطوير مشة قرصية محمولة باليد تعمل بالطاقة الثمسية

[166]

$$
\begin{aligned}
& \text { محمد وافى محمد عرفات1" - مبارك محمد مصطفى2 - فتحى عبد الحليم عبدالهادى حسن3 } \\
& \text { وليلا محمد كامل الحلو } 2 \\
& \text { 1- مديرية الزراعة بالداخلة - محافظة الوادي الجديد - مصر }
\end{aligned}
$$

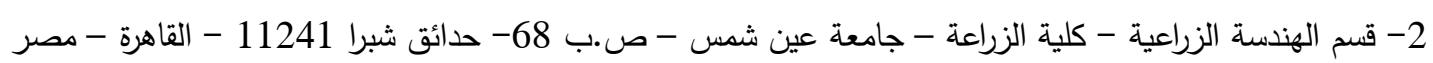

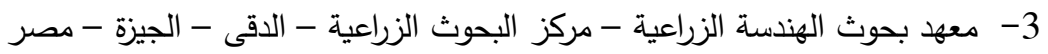

*Corresponding author: smart-eng.202014@agr.asu.edu.eg

Received 16 July, 2019 Accepted 24 September, 2019

والثانية الإختبارات الحقلية لتقييم آداء الآلة المعدلة

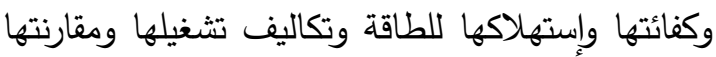

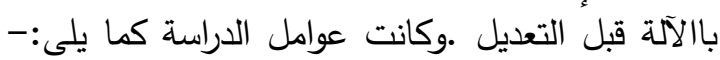

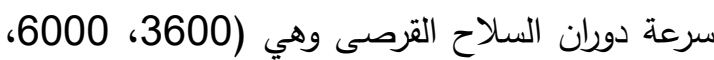
9000 لفة/دقيقة) .والكثافة النباتية للبرسيم الحجازي

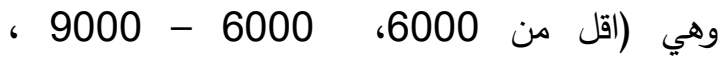
>12000 نبات/2²). ويمكن تلخيص نتائج التجربة

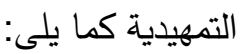
كان متوسط طول ساق نباتات البرسيم الحجازى

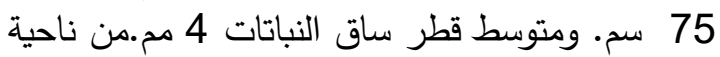
أخرى، تراوحت كثافة النبات بين 6000 إلى 45 بـ 12000

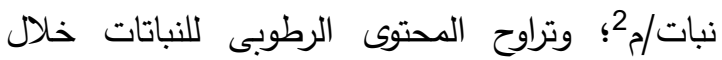
عملية القص ما بين 79 إلى 89٪

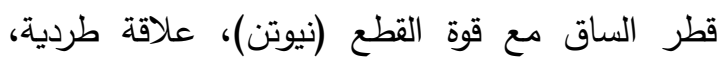

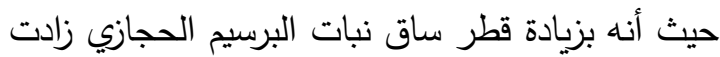

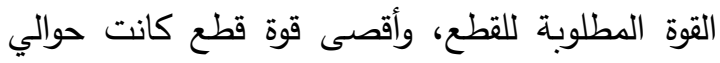

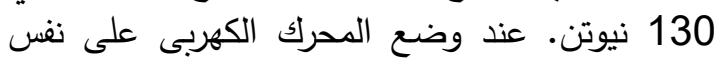

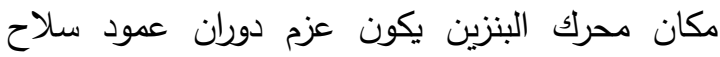
القطع أقل من المطلوب لآداء مقبول للآلّة المقترحة لذان الذان

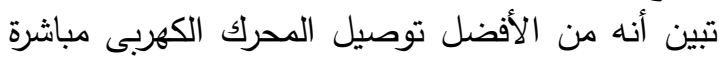

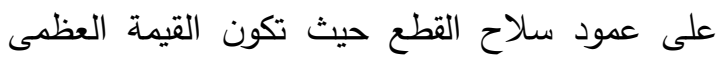
والصغرى للعزم على عمود سلاح القطع 0.6366 و0.2546 نيوتن . متر • والتى سجلت عندما كانت

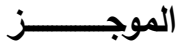

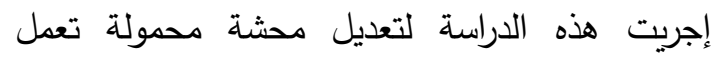

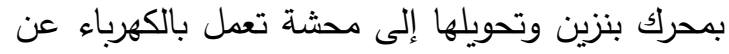

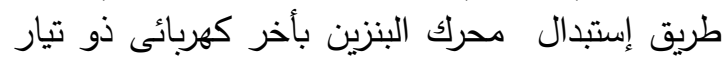
مستمر (DC motor) يستمد القدرة من بطارية جافية 12 فولت يتم شحنها من محطة للطاقة الثمسية بمزرعة خاصة فى منطقة الداخلة بالوادى الجديد، وقد

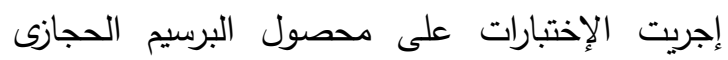

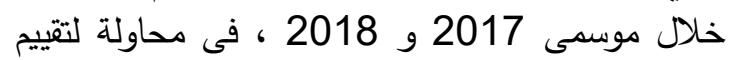

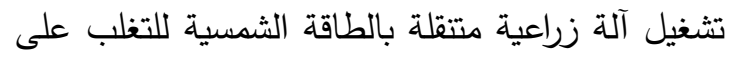

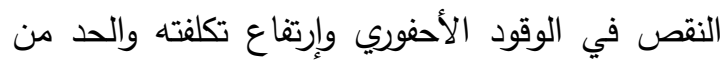

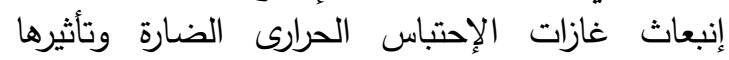

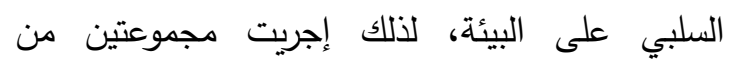

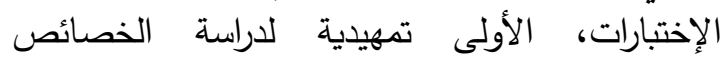

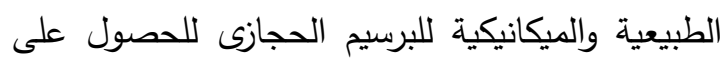
البيانات اللازمة لتطويرالآلة المقترحة وإختيار أجزائها

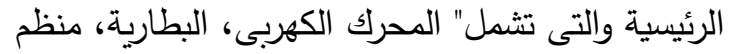

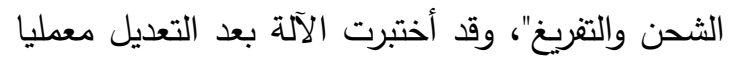

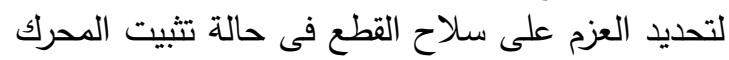

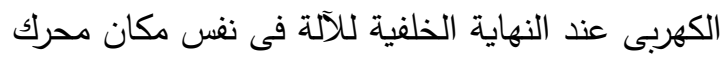

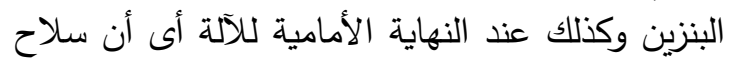
القطع يأخذ الحركة مباشرة من المحرك الكهربى. 
التى تعمل بالطاقة الثمسية بين 60-85\% مع التئة السرعة الدورانيه المتوسطة لسلاح القطع 6000 لفة|دقيقة. تراوحت قيمة الطاقة المستهلكة للآلة التي لإني تعمل بالطاقة الثمسية (بعد التعديل) بين 4.454 كيلواتوات 4.431 4.454 كيلووات. س/فدان. في حين تراوحت الطاقة

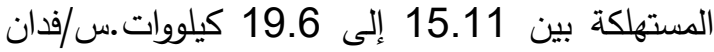
مع الآلة التي تعمل بالبنزين (قبل التعديل).

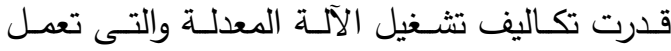

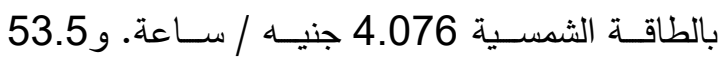

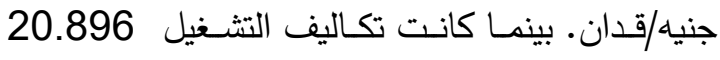
جنيه / ساعة و 67.6 جنيه / فدان عند إستخدام الآلة

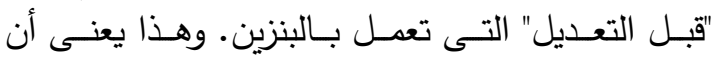

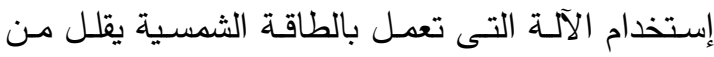
إجمالي تكلفة التشغيل (جنيه /ساعة) بنسبة 80 ٪. الكلمات الدالة: محشه كهربيه محموله، محثه قرصيه،

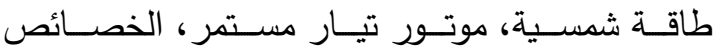
الميكانيكية للبرسيم الحجازي
سرعة سلاح القطع 3600 و 9000 لفة /دقيقة على الترتي الترتيب. وعند إختبار حالة شحن البطارية المختارة تبين أن البطارية يمكن أن تستمر في البـارية (S.O.C)

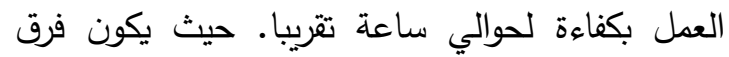
الجهد 14 فولت عند اقصى مستوى شحن البطارية

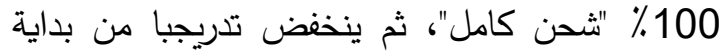

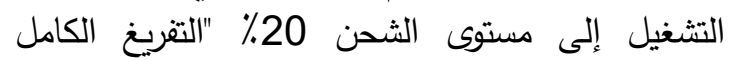
"عندها يكون فرق الجهد 8 فولت، وبالتالى لابد من إعادة شحنها. يتأرجح التيار بين الحد الأقصى 12 أمبير أثناء شوط القطع، لينخفض إلى الثى الحد الأدنى 4

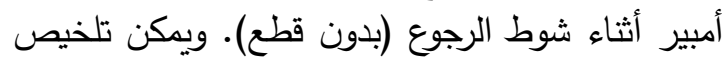
نتائج الإختبارات الحقلية فيما يلى الثي: أظهرت النتائج أن معدل الأداء "الأنتاجية" يزداد فياد بزيادة سرعة سلاح القطع، ويقل بزيادة الكثافة النباتية.

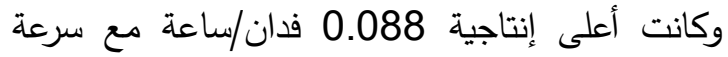
سلاح القطع 9000 ل/د، وكثافة نباتية حوالي 6000

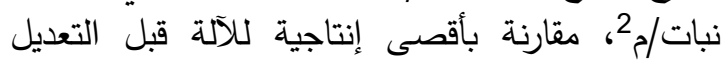
كانت 0.209 فدان/ساعة. تراوحت كفاءة القطع للآلة 